\title{
ISOLATION OF EXTRACELLULAR PHYTASE PRODUCING LACTIC ACID BACTERIA FROM THE GASTRO INTESTINAL TRACT OF POULTRY BIRDS
}

\author{
Aima Airenobuwa DAODU1, Gbemisola Deborah OLUMUYIDE ${ }^{1}$, and Lawrence EDEMHANRIA2 ${ }^{2} \bowtie$ \\ ${ }_{1}^{1}$ Department of Biological Sciences, Samuel Adegboyega University, PMB 0001, Ogwa, Nigeria \\ 2Department of Chemical Sciences, Samuel Adegboyega University, PMB 0001, Ogwa, Nigeria \\ Email: ledemhanria@gmail.com; Phone: +2349055159224; (1DORCiD: 0000-0002-6034-3780 \\ supporting Information
}

\begin{abstract}
Bacterial phytases and phytase-producing bacteria are of great industrial significance in the poultry industry and also in phosphorus pollution management. This study was designed to isolate and screen for phytase producing lactic acid bacteria from the duodenum, ileum and cecum of eight healthy cockerel samples. Standard microbiological procedures were followed to isolate phytase producing lactic acid bacteria using de Man Rogosa and Sharp (MRS) agar while extracellular phytase screening was done using phytase specific medium. The range of total microbial count obtain was highest at the cecum $\left(2.85 \pm 0.11\right.$ to $4.34 \pm 0.12 \log _{10}$ $\mathrm{cfu} / \mathrm{ml})$, lower at the duodenum $\left(2.02 \pm 0.11\right.$ to $\left.4.27 \pm 0.20 \log _{10} \mathrm{cfu} / \mathrm{ml}\right)$ and lowest at the ileum $(2.00 \pm 0.21$ to $\left.4.19 \pm 0.25 \log _{10} \mathrm{cfu} / \mathrm{ml}\right)$. Nineteen bacterial isolates were identified as lactic acid bacteria on the basis of morphological, biochemical and physiological characterization and later identified as Lactobacillus species (78.94\%), Enterococcus species (15.78\%) and Lactococcus species (5.26\%). Thirteen out of the nineteen lactic acid bacteria showed phytase activity. Low phytase activity was observed in eight of the lactic acid bacteria isolates while five of the isolates produced significant extracellular phytase activity $(>6 \mathrm{~mm})$. The most predominant Lactobacillus species were also found to be the most potent phytase producers. This can be exploited for industrial production of phytase in upgrading the nutritional status of feed and combating phosphorus pollution from poultry waste.
\end{abstract}

Keywords: Phytase, Gastrointestinal tract, Lactic acid bacteria, Phosphorus pollution, Poultry industry.

\section{INTRODUCTION}

Phosphorus is an important nutrient stored in the form of phytic acid (Myo-inositol 1,2,3,4,5,6-hexakis dihydrogen phosphate) in cereals, legumes, and oilseed crops (Azeke et al., 2007). Phytic acid acts as antinutrient constituent in plant-derived food and feed as it forms complexes with proteins, amino acids, and various metal ions (Astley and Finglas, 2016; Nissar et al., 2017). The bound phosphorus is poorly available to monogastric animals such as pigs, poultry and fishes, due to lack of production of phytases in the gastrointestinal tract (Jacela et al., 2010; Abdel-Megeed and Tahir, 2015). Excretion of the undigested phytate poses a serious phosphorus pollution problem contributing to eutrophication in areas of intensive livestock production (Singh et al., 2011; Abdel-Megeed and Tahir, 2015). The enzyme phytase hydrolyzes the ester bond in phytic acid to liberate inositol and inorganic phosphate (Nissar et al., 2017). It can be sourced from some plants, animal tissues and microorganisms; microbial sources are however more promising for the commercial production of phytases (De Angelis et al., 2003).

Phytases have been obtained mainly from filamentous fungi (Maller et al., 2013); it has also been detected in various bacteria species such as Bacillus, Pseudomonas, Escherichia coli, Enterobacter, Klebsiella, Lactobacillus sanfranciscensis as well as anaerobic rumen bacteria, particularly in Selenomonas ruminantium, Megasphaera elsdenii, Prevotella sp., Mitsuokella multiacidus and Mitsuokella jalaludinii (Shim and Oh, 2012).

Species of lactic acid bacteria (LAB) belonging to numerous genus under the family of Lactobacillaceae have been widely applied in food fermentation worldwide due to their widely known status as generally recognized as safe (GRAS) microorganisms (Hayek and Ibrahim, 2013). They are also recognized for their fermentative ability which contributes to enhancing food safety, improving organoleptic attributes, enriching nutrients and increasing health benefits (Sharma et al., 2012; Steele et al., 2013). There are only few reports of phytase producing lactic acid bacteria available in literature, therefore this present study was designed to isolate phytase producing lactic acid bacteria from the gastrointestinal tract of poultry. The addition of phytase to poultry feed will improve the nutritional quality of feed by increasing the amount of free phytate phosphorus in poultry diet and diminishing the necessity of addition of inorganic phosphate to animal feed, thereby combating phosphorus pollution associated with the feed and poultry industries. 


\section{MATERIALS AND METHODS}

\section{Ethical Approval}

The Ethics Unit of the Research and Innovation Committee of Samuel Adegboyega University approved the study protocol.

\section{Study Area}

The study was carried out at College of Basic and Applied Sciences, Samuel Adegboyega University, Ogwa in Esan West Local Government Area of Edo State, Nigeria.

\section{Sample collection and preparation}

Eight cockerels were purchased from Global Poultry, Uromi, Esan North East Local Government Area, Edo State, Nigeria. The gastrointestinal tracts of the eight chickens were aseptically collected in ten sterile plastic bags and transported to the laboratory in ice packs for microbiological analysis. The samples were represented with codes A-H. The duodenum, ileum and cecum represented with codes $d$, i and $c$ for each of the eight samples were removed separately under sterile conditions to give a total of twenty-four samples.

\section{Enumeration and isolation of bacteria}

Ten grams of the duodenum, ileum and cecum respectively for each sample was weighed aseptically and transferred into a sterile beaker containing $100 \mathrm{ml}$ of normal saline. Six-fold serial dilution $\left(10^{-1}\right.$ to $\left.10^{-6}\right)$ was made using normal saline. An aliquot of $1 \mathrm{ml}$ of the appropriate six-fold serial dilution $\left(10^{-2}\right)$ of the intestinal samples were inoculated into the de Man Rogosa and Sharp (MRS) agar plates using standard pour plate method and incubated anaerobically at $37^{\circ} \mathrm{C}$ for 36 hours. Visible discrete colonies on inoculated plates were counted using the colony counter and expressed in colony forming units per millilitre $(\mathrm{cfu} / \mathrm{ml})$ of the intestinal sample. Discrete colonies were selected and purified by subculturing in MRS broth. Further purification was carried out by repeated streaking on freshly prepared MRS agar plates. The pure isolates were stored at $4^{\circ} \mathrm{C}$ using MRS agar slants.

\section{Characterization and identification of bacterial isolates}

Pure cultures of all isolates were characterized and identified by means of their cultural, morphological, physiological and biochemical characteristics using Bergey's manual of systematic Bacteriology (Holt et al., 1994)

\section{Phytase activity screening}

The isolated pure strains were screened for the production of extracellular phytase using phytase specific medium (Chunshan et al., 2001). The phytase screening medium was prepared by dissolving $3 \mathrm{~g}$ glucose; $1 \mathrm{~g}$ Tryptone; $1 \mathrm{~g}$ sodium phytate; $0.3 \mathrm{~g} \mathrm{Cacl}_{2} ; 0.5 \mathrm{~g} \mathrm{MgSO}_{4} ; 0.04 \mathrm{~g} \mathrm{MnCl}_{2} ; 0.0025 \mathrm{~g} \mathrm{FeSO}_{4}$; and $15 \mathrm{~g}$ agar in 1 litre of distilled water. The pure cultures were streaked at the centre of the plate and the plates were incubated at $37^{\circ} \mathrm{C}$ for 62 hours as described by Kumar et al. (2011). The plates were then observed for formation of clear zone around the colony. A clear zone around the colony indicates positive result. Only those with zones greater than $6 \mathrm{~mm}$ in diameter were recorded as significant.

\section{Data analysis}

The mean, standard error of mean, one way ANOVA and Tukey's Post Hoc analysis were done using IBM SPSS Statistics 23 software for Windows. P value $<0.05$ was statistically significant.

\section{RESULTS}

The total bacterial count from the duodenum, ileum and cecum of the eight chicken samples are presented in Table 1. A total of fifty-seven bacteria isolates were randomly selected based on distinct colony morphology and purified. The morphological, physiological and biochemical characteristics of the pure isolates revealed that $49.12 \%$ of the bacterial isolates were white, viscous, entire, glistering and raised. $10.53 \%$ were creamy, viscous, entire, glistering and flat. $26.32 \%$ were white, viscous, entire, glistering and raised. $12.28 \%$ were white, dry, entire, rough and raised. $1.75 \%$ were creamy, viscous, entire, glistering and raised. Nineteen out of the fifty-seven bacterial isolates were presumed as lactic acid bacteria on the basis of gram stain reaction, catalase production and oxidase activity. The isolates were gram positive short rods and cocci, catalase negative and oxidase negative. Further presumptive tests including growth at temperature $10^{\circ} \mathrm{C}$ and $45^{\circ} \mathrm{C}$, growth at $\mathrm{pH} 4.5$ and 6.5 , gas production from glucose and ability to ferment various carbohydrates (lactose, maltose, sucrose and glucose) performed indicated that growth was recorded for all the isolates at $\mathrm{pH} 4.5$ and pH 6.5 at $45^{\circ} \mathrm{C}$ only. The isolates were identified as Lactobacillus, Lactococcus and Enterococcus species. The percentage occurrence of the lactic acid bacteria isolates is shown in Figure 1. Thirteen out of the nineteen lactic acid bacteria isolates showed phytase activity by hydrolyzing sodium phytate to form a clear zone around the colony (Table 2). Five bacterial isolates, all Lactobacillus species, (Dc2, Dd2, Dd4, Fd1 and Fc3) had a significantly different $(p<0.05)$ ability to hydrolyze phytate by forming a clear zone $>6 \mathrm{~mm}$. 
Table 1 - Total bacterial counts $\left(\log _{10} \mathrm{cfu} / \mathrm{ml}\right)$ from the gastrointestinal tracts of samples.

\begin{tabular}{cccc} 
Sample & Duodenum & lleum & Cecum \\
\hline A & $2.02 \pm 0.11$ & - & $2.85 \pm 0.11$ \\
B & $2.26 \pm 0.17$ & $2.00 \pm 0.21$ & $3.88 \pm 0.14$ \\
C & $3.77 \pm 0.12$ & $2.98 \pm 0.25$ & - \\
D & $4.27 \pm 0.20$ & $4.11 \pm 0.20$ & $3.37 \pm 0.14$ \\
E & $2.03 \pm 0.15$ & $3.23 \pm 0.22$ & $4.34 \pm 0.11$ \\
F & $2.57 \pm 0.38$ & $4.05 \pm 0.13$ & $3.53 \pm 0.12$ \\
G & $3.57 \pm 0.37$ & $4.19 \pm 0.25$ & $3.90 \pm 0.18$ \\
H & $3.85 \pm 0.33$ & $3.65 \pm 0.25$ & $3.69 \pm 0.11$ \\
\hline Values are mean \pm standard error of mean of triplicate determinations. - = Absent, A-H = Isolation codes for the 8 chicken samples.
\end{tabular}

\section{Table 2 - Phytase screening of lactic acid bacteria from the gastrointestinal tract of poultry samples}

\begin{tabular}{|c|c|c|c|c|}
\hline $\mathbf{S} / \mathbf{N}$ & Isolation code & Hydrolysis of phytate & Clear zone (mm) & Probable bacterial species \\
\hline 1 & Ad1 & + & $5.13 \pm 1.02^{a}$ & Lactococcus \\
\hline 2 & Bc1 & + & $3.24 \pm 0.86^{b}$ & Lactobacillus \\
\hline 3 & Dc2 & + & $9.26 \pm 2.11^{c}$ & Lactobacillus \\
\hline 4 & Dd1 & - & 0 & Enterococcus \\
\hline 5 & Dd2 & + & $11.21 \pm 1.32^{d}$ & Lactobacillus \\
\hline 6 & Dd3 & + & $5.42 \pm 1.51^{\mathrm{a}}$ & Enterococcus \\
\hline 7 & Dd4 & + & $8.25 \pm 0.93^{e}$ & Lactobacillus \\
\hline 8 & Dd5 & - & 0 & Lactobacillus \\
\hline 9 & Dd6 & - & 0 & Lactobacillus \\
\hline 10 & Dd7 & - & 0 & Lactobacillus \\
\hline 11 & Di3 & + & $4.18 \pm 1.44^{f}$ & Lactobacillus \\
\hline 12 & Ei1 & - & 0 & Lactobacillus \\
\hline 13 & $\mathrm{Ei} 2$ & + & $5.22 \pm 0.76^{a}$ & Enterococcus \\
\hline 14 & Fd1 & + & $8.33 \pm 0.43$ eg & Lactobacillus \\
\hline 15 & Fd2 & + & $2.38 \pm 1.63^{h}$ & Lactobacillus \\
\hline 16 & Fc3 & + & $7.44 \pm 0.88^{e i}$ & Lactobacillus \\
\hline 17 & $\mathrm{Fi} 2$ & - & 0 & Lactobacillus \\
\hline 18 & Gi1 & + & $5.23 \pm 1.05^{a}$ & Lactobacillus \\
\hline 19 & Gi3 & + & $6.00 \pm 1.32^{a}$ & Lactobacillus \\
\hline
\end{tabular}

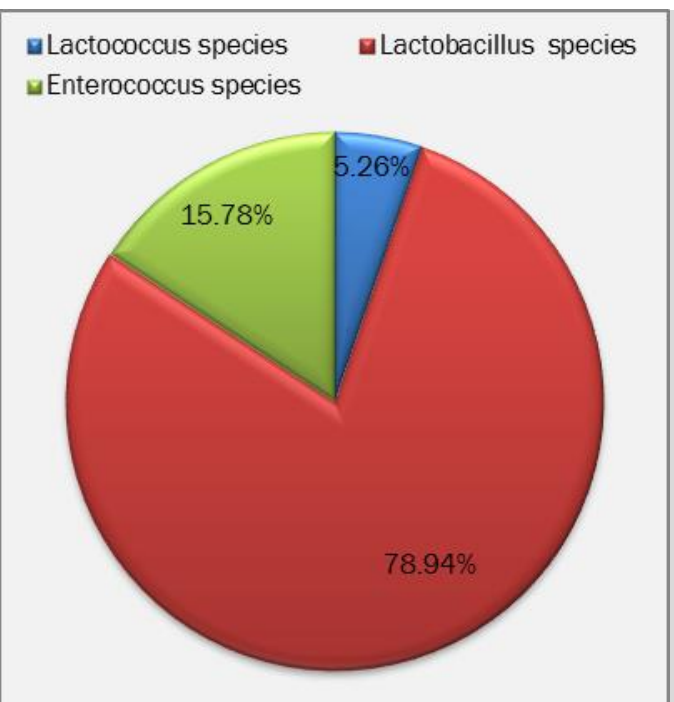

Figure 1 - Percentage occurrence of lactic acid bacteria isolates from gastrointestinal tract of poultry samples 


\section{DISCUSSION}

The bacteria growth recorded in the duodenum, ileum and cecum of all the chicken samples had different growth count range (Table 1). The variation in the microbial population suggests that each region developed its own unique bacterial community due to the $\mathrm{pH}$ of the stomach contents, the toxicity of bile salts, fermentative metabolism and the relatively swift flow of the digesta in the gastrointestinal tract (Walter, 2008). This result agrees with the findings of other researchers available in literature. Jiangrang et al. (2003) reported differences in the diversity of bacterial floras in the ilea and ceca of maturing broiler chickens; Bjerrum et al. (2006) investigated microbial communities in the ileum and cecum of broiler chickens, they reported that lactobacillus species dominated the chicken ileum while the cecum harbored more diverse microbial community and Abbas et al. (2007) identified various levels of abundance of different lactobacillus species from the crop of 1- and 5- week old broiler chickens using 16s rRNA gene sequence.

The isolates were identified as Lactobacillus species, Lactococcus species and Enterococcus species. Previous studies confirm the existence of these organisms in the gastrointestinal tract of chicken (Lan et al., 2003; Sonplang et al., 2007). The Lactobacillus species were more dominant because of their ability to adhere to the surface of the non-secretary epithelium lining of these sites, which enables the bacteria to form a biofilm-like structure that provides a bacterial inoculum of the digesta (Salas-Jara et al., 2016). Different studies on the microbiota of the gastrointestinal tract of poultry have pointed out the predominance of lactobacilli in chicken crops and intestine (Beasley et al., 2004; Bakari et al., 2011).

Thirteen out of the nineteen lactic acid bacteria showed phytase activity, suggesting that they could be a potential source of phytase to be used in improving the nutritional quality of poultry diet and decreasing the amount of phosphorus released to the environment (Hill et al., 2007; Abdel-Megeed and Tahir, 2015). Five of the Lactobacillus species were found to be the most potent phytase producers. Phytase producing ability of lactic acid bacteria has also been reported in some previous studies. Raghavendra and Halami (2009) isolated forty lactic acid bacterial strains with phytate degrading ability while Anastasio et al. (2010) reported the use of lactic acid bacteria to improve mineral solubilization during dough fermentation due to their production of phytate-degrading enzymes.

\section{CONCLUSION}

In this study, phytase producing lactic acid bacteria were isolated from the gastrointestinal tract of healthy cockerels. These findings can be further explored in the industrial production of phytase. It will be of immense benefit to the poultry industry. Feed supplementation with phytase will help to improve the nutritional status of the feed. This also has implication for environmental management as it would lead to a reduction in phosphorus pollution.

\section{DECLARATIONS}

\section{Competing interest}

The authors declare that they have no competing interest.

\section{Ethics}

The research was done following ethical procedures.

\section{Authors' contribution}

AAD, LE designed the experiment; AAD, GDO carried out data collection; LE performed data analysis; AAD, GDO and LE contributed in manuscript preparation and approval for publication.

\section{REFERENCES}

Abbas Hilmi H, Surakka A, Apajalahti J and Saris PEJ (2007). Identification of the most abundant lactobacillus species in the crop of 1and 5-week-old broiler chickens. Applied and Environmental Microbiology. 73: 7867-7873. DOI: https://dx.doi.org/10.1128/AEM.01128-07.

Abdel-Megeed A and Tahir A (2015) Reduction of phosphorus pollution from broilers waste through supplementation of wheat based broilers feed with phytase. Journal of Chemistry 2015:1-3. DOl:_https://dx.doi.org/10.1155/2015/867014.

Anastasio M, Pepe 0, Cirillo T, Palomba S, Blaiotta G and Villani F (2010). Selection and use of phytate degrading LAB to improve cerealbased products by mineral solubilization during dough fermentation. Journal of Food Science 75: 28-35. DOI: https://dx.doi.org/10.1111/j.1750-3841.2009.01402.x.

Astley S and Finglas P (2016). Nutrition and health In: Reference module in food sciences. Elsevier Publications, UK. pp 1-6. DOI: https://dx.doi.org/10.1016/B978-0-08-100596-5.03425-9.

Azeke MA, Fretzdorff B, Buening-Pfaue H and Betsche TH (2007). Nutritional value of African yambean (Sphenostylisstenocarpa, L.): improvement by solid substrate fermentation using the tempeh fungus Rhizopus oligosporus. Journal of the Science of Food and Agriculture. 87(2):297-304. DOI: https://dx.doi.org/10.1002/jsfa.2721.

Bakari D, Tatsadjieu NL, Mbawala A and Mbofung CM (2011). Assessment of physiological properties of some lactic acid bacteria isolated from the intestine of chickens used as probiotics and antimicrobial agents against enteropathogenic bacteria. Innovative Romanian Food Biotechnology. 8:33-40. Google Scholar 
Beasley SS, Takala TM, Reunanen J, Apajalahti J and Saris PE (2004). Characterization and electrotransformation of Lactobacillus crispatus isolated from chicken crop and intestine. Poultry Science. 83:45-48. DOI: https://dx.doi.org/10.1093/ps/83.1.45

Bjerrum L, Engberg RM, Leser TD, Jensen BB, Finster K (2006). Microbial Community Composition of the ileum and cecum of broiler chickens as revealed by molecular culture-based techniques. Poultry Science 85: 1151-1164. D0I: https://dx.doi.org/10.1093/ps/85.7.1151.

Bohn L, Meyer AS and Rasmussen S (2008). Phytate: impact on environment and human nutrition. A challenge for molecular breeding. Journal of Zhejiang University-Science B9:165-191. DOI: https://dx.doi.org/10.1631/jzus.B0710640.

Chunshan Q, Linghua Z, Yunji W, Yoshiyuki O (2001). Production of phytase in a low phosphate medium by a novel yeast Candida krusei. Journal of Bioscience and Bioengineering 92: 154-160. DOI: https://dx.doi.org10.1263/jbb.92.154.

De Angelis M, Gallo G, Corbo MR, McSweeney PL, Faccia M, Giovine M, Gobbetti M (2003). Phytase activity in sourdough lactic acid bacteria: purification and characterization of a phytase from Lactobacillus sanfranciscensis CB1. International Journal of Food Microbiology. 87(3):259-70. DOI: https://dx.doi.org/10.1016/s0168-1605(03)00072-2

Hayek SA and Ibrahim SA (2013). Current Limitations and Challenges with Lactic Acid Bacteria: A Review. Food and Nutrition Sciences 4:73-87. DOI: https://dx.doi.org/10.4236/fns.2013.411A010.

Hill JE, Kysela D and Elimelech M (2007). Isolation and assessment of phytate hydrolysing bacteria from the DelMarVa peninsula. Environmental Microbiology 9: 3100-3107. DOI: https://dx.doi.org/10.1111/j.1462-2920.2007.01420.x.

Holt JG, Kreig NR, Sneath PHA, Staley JT and Williams ST (1994). Bergey's Manual of Determinative Bacteriology, $9^{\text {th }}$ Edition. Williams and Wilkins, Baltimore, USA. Google Scholar

Jacela JY, DeRouchey JM, Tokach MD, Goodband RD, Nelssen JL, Renter DG and Dritz SS (2010). Feed additives for swine: Fact sheets prebiotics and probiotics and phytogenics. Journal of Swine Health and Production 18: 87-91. Google Scholar

Jiangrang L, Umelaalim I, Barry H, Charles H, Maurer JJ and Margie D (2003). Diversity and Succession of the Intestinal Bacteria Community of the Maturing Broiler Chicken. Applied and Environmental Microbiology 69(11): 6816-6824. DOI: https://dx.doi.org/10.1128/AEM.69.11.6816-6824.2003.

Kumar DJ, Balakumaran MD, Kalaichelvan PT, Pandey A, Singh A and Raja RB (2011). Isolation, production \& application of extracellular phytase by Serratia marcescens. Asian Journal of Experimental Biosciences 2 (4): 663-666. Google Scholar

Lan PTN, Binh LT, Benno Y (2003). Impact of two probiotic Lactobacillus strains feeding on fecal lactobacilli and weight gains in chicken. The Journal of General and Applied Microbiology. 49:29-36. DOI: https://dx.doi.org/10.2323/jgam.49.29

Maller A, Vici AC, Facchini FDA, da Silva TM, Kamimura ES, Rodrigues MI, Jorge JA, Terenzi HF and Polizeli MLTM (2013). Increase of the phytase production by Aspergillus japonicus and its biocatalyst potential on chicken feed treatment. Journal of Basic Microbiology. 53:1-9. DOI: https://dx.doi.org/10.1002/jobm.201300315.

Nissar J, Ahad T, Naik HR and Hussain SZ (2017). A review of phytic acid: As antinutrient or nutraceutical. Journal of Pharmacognsy and Phytochemistry. 6(6):1554-1560. Google Scholar

Raghavendra P and Halami PM (2009). Screening, selection and characterization of phytic acid degrading lactic acid bacteria from chicken intestine. International Journal of Food Microbiology. 133: 129-134. DOI: https://dx.doi.org/10.1016/j.ijfoodmicro.2009.05.006.

Salas-Jara MJ, Ilabaca A, Vega M, García A. (2016). Biofilm forming Lactobacillus: new challenges for the development of probiotics. Microorganisms. 4:35. DOI: https://dx.doi.org/10.3390/microorganisms4030035.

Sharma R, Sanodiya BS, Bagrodia D, Pandey M, Sharma A and Bisen PS (2012). Efficacy and Potential of Lactic Acid Bacteria Modulating Human Health. International Journal of Pharma and Bio Sciences. 3(4): 935-948. Google Scholar

Shim JH and Oh BC (2012). Characterization and application of calcium-dependent beta-propeller phytase from Bacillus amyloliquefaciens DS11. Journal of Agricultural and Food Chemistry. 40 (32):9669-9676. DOI: https://dx.doi.org/10.1021/jf3022942.

Singh B, Kunze G and Satyanarayana T (2011). Developments in biochemical aspects and biotechnological applications of microbial phytases. Biotechnology and Molecular Biology Review. 6: 69-87. Google Scholar

Sonplang P, Uriyapongson S, Poonsuk K and Mahakhan P (2007). Lactic acid bacteria isolated from native chicken feces. KKU Veterinary Journal. 17:33-42. Google Scholar I AGRIS

Steele J, Broadbent J and Kok J (2013) Perspective on the contribution of lactic acid bacteria to cheese flavor development. Current Opinion in Biotechnology. 24(2):135-214. DOI: https://dx.doi.org/10.1016/i.copbio.2012.12.001.

Walter J (2008). Ecological role of Lactobacilli in the gastrointestinal tract: implications for fundamental and biomedical research. Applied and Environmental Microbiology. 74:4985-4996. DOI: https://dx.doi.org/10.1128/AEM.00753-08. 